\title{
Методы и приемы преподавания теории литературы во внеурочных занятиях
}

\author{
Потапова Е.А., магистрант, \\ Северо-Восточный федеральный университет, \\ 2. Якутск \\ E-mail: zheeenya94@mail.ru
}

Научный руководитель: к.n.н., доцент Олесова С.Г.

Совершенствование преподавания литературы в школе предполагает усиление нравственного, эстетического и эмоционального воздействия литературного произведения на читателя-школьника, определение системных связей школьного курса литературы на разных этапах литературного образования, воспитание самосознания и самостоятельности, развитие читательского восприятия и интереса к изучаемой литературе, развитие воображения и чувства прекрасного, формирование творческого подхода к литературе.

Особое внимание изучению теории литературы следует уделять в среднем звене, т.к. именно в этот период школьного курса изучаются наиболее сложные произведения, кроме того, чтение художественных текстов проходит наиболее осмысленно. Грамотное использование теории литературы во многом может способствовать повышению интереса старшеклассником к изучаемым произведениям. В этом заключается актуальность данной статьи.

Цель исследования: выявление методов и приемов преподавания теории литературы в школе и применение их во внеклассных занятиях.

Для решения поставленной цели в работе будут решаться следующие задачи:

- Анализ педагогических и методических исследований;

- Преподавание теории литературы, виды и типы работ;

- Разработка рабочей тетради в 7 классе, предназначенная для обучения теории литературы;

- Организация и проведение самостоятельной работы учащегося с помощью рабочей тетради.

Объект исследования: методы и приемы преподования теории литературы в 7 классе.

Предмет исследования: организация и проведение преподавания теории литературы во внеурочных занятиях.

Гипотеза исследования: организация и проведение преподавания теории литературы во внеурочных занятиях может быть успешным, если:

- учитель успешно будет пользоваться методами и приемами преподавания теории литературы во внеклассных занятяих с целью развития читательского восприятия и интереса к изучаемой литературе у учащихся;

- умело и искусно использовать методы и приемы, учитывая возраст, навыки, возможности и интересы учащихся;

- учитель и ученик будут успешно работать, погружаясь в творческую деятельность;

- умело использовать рабочую тетрадь во внеклассных работах и занятиях. 
Новизна: разработка рабочей тетради по теории литературы во внеклассных занятиях.

Теория литературы - это один из основных разделов науки о литературе, изучающий природу и общественную функцию литературного творчества и определяющий методологию и методику его анализа.

Изучение теории литературы актуальна в методике преподавания литературы. Методы и приемы преподавания теории литературы в школе исследовали такие русские ученые и методисты, как В.В.Голубков («Методика преподавания литературы», 1962г.), М.А.Рыбникова («Очерки по методике литературного чтения», 1963с.), В.А.Никольский («Методика преподавания литературы в средней школе», 1971г.), Г.И.Беленький («Теория литературы в средней школе», 1976г.), М.А.Снежневская («Теория литературы в 4-6 классах средней школы», 1978г., «Изучение теории литературы в средней школе», 1983г.), Н.И.Кудряшев («Взаимосвязь обучения на уроках литературы», 1981г.), 3.Я.Рез («Методика преподавания литературы»), В.Г.Маранцман, О.Ю.Богданова, С.А.Леонов, В.Ф.Чертов («Методика преподавания литературы», 1999 г.), ону тэнэ А.Г.Балыбердин, С.К.Бирюкова, Н.Н.Вербова, Г.К.Звягинцева, М.Г.Качурин, Т.Ф.Курдюмова, Н.И.Прокофьев, Л.В.Тодоров, В.Р.Щербин и др. На основании и примере русских ученых, вопросы методики преподавания якутской литературы, а также изучения теории литертуры в школе, стали исследовать такие якутские методисты, как Н.И.Филиппова («Төрөөбүт литератураны 4-7 кылаастарга үөрэтии»), Е.М.Поликарпова («Хоһоонноохтук аақыы»), С.К.Колодезников («Актуальные вопросы литературного образования в общеобразовательной школе», 2009г.), Е.К.Иевлев и др.

Общие принципы и приемы теории литературы в школе обоснованы в фундаментальном труде академика В.В. Голубкова: «Формирование у учащихся основных понятий в области той или иной дисциплины, имеющие целью дать им систему научных знаний, составляет одну из главных задач нашей школы. Но эта работа по формированию понятий, так же, как и все другие виды учебных занятий, должна быть поставлена в тесную связь с общими задачами. В противном случае она рискует превратиться в пустой формализм. Такая опасность угрожает и преподавателю литературы, если только он станет рассматривать формирование теоретиколитературных понятий у учащихся, как нечто самодовлеющие, как особый раздел работы, стоящий рядом с изучением произведений и развитием речи [4].

«Литература - вид искусства», - пишет М.А.Рыбникова [5]. Ученик должен знать основные понятия теории литературы. Исходя из этого, он не только знакомится с писателем и его произведением, но и учится ценить и уважать его и его творчество, при этом развивает логическое мышление, воображение и творческие навыки. Как отмечает методист, с помощью изучения теории литературы, учителя прививают учащихся к культуре чтения и творческой работе.

Методист Н.И.Филиппова, основываясь на работах русских методистов, также выявила методы и приемы изучения теории литературы в школе. Например, картина и сочинение выступают в виде методов и приемов для изучения композиции; рассказ учителя, сравнение, вопросы, сочинение - для изучения портрета художественного героя, использование видов искусства - для подробного изучения художественных средств языка.

Основным приемом изучения и закрепления теоретико-литературных положений является анализ художественного произведения [8]. Наиболее сложным и интересным нам представляется анализ лирического произведения в связи с тем, что именно в 
стихотворной форме воплощаются, не только мысли и переживания писателя, как это происходит в прозаических произведениях, но и, прежде всего, основу поэтического текста составляют эмоции поэта, грамотный анализ которых, как на литературоведческом, так и на лингвистическом уровне (использование тропов и т.д.) помогает понять и прочувствовать замысел автора.

Теория литературы помогает раскрыть суть, внутренний мир произведения, отношение автора к героям, а также способствует развитию творческих навыков у учащихся. Изучив методы и приемы для изучения теории литературы в школе, которые представлены в работах методистов и ученых, была разработана рабочая тетрадь, которая предназначена для учащихся 7 классов, т.к. в этом звене теория литературы приобретает наиболее углубленное изучение. На уроках литературы особое внимание уделяется автору и произведению, следовательно, рабочую тетрадь можно использовать во внеклассных занятиях. В ней даны разные по сложности задания, которые распределены по пунктам: 1. «Домашняя работа» («Дьиэ үлэтэ») - для закрепления и углубления знаний, умений и навыков, полученных на уроке; 2. «Углубленное изучение» («Диринэтэн үөрэтии»), предназначен для учеников, которые углубленно изучают устное народное творчество и художественную литературу; задания этого пункта могут выполнить ученики-олимпиадники, ученики, которые участвуют в различных предметных конкурсах и конференциях; 3. «Дополнительные задания» («Эбии дьарык»), которые предназначены для тех учеников, которые по уважительным причинам пропускают урок литературы; 4. «Внеклассная работа» («Анал дьарык»), задания, которые направлены на углубление и закрепление знаний учащихся с последующим применением их на практике. Также отдельно представлен пункт «Творческая работа» («Айар айымньылаах үлэ»), который способствуют раскрытию индивидуальных способностей, творческого и личностного потенциала ребенка, его умений и навыков, которые не всегда можно рассмотреть на уроке. Помимо этого, к каждому заданию присвоен определенный условный знак, с помощью которого ученик может определить, какими умениями и навыками он должен воспользоваться для выполнения данного задания (например, “уруһуйдаa”, “суруй,” “тылдьытынан үлэ”, “өйдөө”, “аах”, “айар айымньылаах үлэ”, “иһит”). К рабочей тетради прикреплен словарь литературных терминов, который основан на работах Васильева Г.М. «Нууччалыы-сахалыы поэтическай тылдьыт» («Якутско-русский поэтический словарь», 1976 г.) и Окороковой В.Б. «Литература теорията» («Теория литературы», 2000 г.). С помощью этого словаря ученикам будет намного легче выполнять задания, которые даны в рабочей тетради.

Все представленные задания способствуют развитию творческих способностей у учащихся, а также прививают интерес к творчеству писателя, его мастерству и произведению, как к отдельному виду искусства.

Изучив работы педагогов, методистов, выяснив методы и приемы преподавания теории литературы, можно сделать следующие выводы:

1. Таинство создания произведения - теория литературы. Мастерство писателя кроется в его произведениях, которые он создает с целью воспитать и развить в человеке, в данном случае в ученике, гуманность, способность воображения чувства прекрасного. С помощью произведения мы узнаем о жизни намного больше и учимся находить выходы из трудных жизненных ситуаций.

2 Цель изучения теории литературы в школе - это знание основной мысли и идеи художественного произведения, а также для восприятия учеником мастерства писателя и таинство создания произведения. 
3. Знание теории литературы способствует пониманию и восприятию природы произведения.

4. Следует помнить, что только после прочтения и разбора произведения можно вступить в этап по изучению теории литературы, чтобы достичь ожидаемых результатов. Ученик не только узнает о теории литературы, но и знакомится с индивидуальным творческим почерком писателя, с его идеостилем.

Список литературы:

1. Беленький Г.И. Теория литературы в средней школе. Пособие для учителя. М., «Просвещение», 1976, 222с.

2. Беленький Г.И., Снежневская М.А. Изучение теории литературы в средней школе (4-10 классы): Пособие для учителя. - М.: Просвещение, 1983. - 256 с. - (Б-ка учителя лит.).

3. Богданова О.Ю. и др. Методика преподавания литературы: Учебник для студ. пед. вузов / О.Ю.Богданова, С.А.Леонов, В.Ф.Чертов; Под ред. О.Ю.Богдановой. - М.: Издательский центр «Академия», 1999. - 400 с.

4. Голубков В.В. Методика преподавания литературы. - Москва: Учпедгиз, 1962. -489 c.

5. Рыбникова М.А. Очерки по методике литературного чтения: Пособие для учителя. - 4-е изд., испр.-М.: Просвещение, 1985. - 288с. - (Б-ка учителя лит.).

6. Саха литературатын оскуолақа үөрэтии методиката: Учууталга кинигэ / Саха Өрөсп. төрүт омуктар оскуолаларын чинчийэр ин-т; [эпп.ред. Е.М.Поликарпова]. Дьокуускай: Бичик, 2006. - 288c. (Саха оскуолатын учууталыгар көмө).

7. Снежневская М.А. Теория литературы в 4-6 классах средней школы. Пособие для учителей. М., «Просвещение», 1978, 176с.

8. Филиппова Н.И. Төрөөбүт литератураны 4-7 кылаастарга үөрэтии. Якутскай: Кинигэ изд-вота, 1985. - 144 с.

9. Филиппова Н.И. Төрөөбүт литератураны кылаас таһынан аақыы методиката. Саха оскуолатын 5-9 кылаастарыгар. Учууталга пособие: - Якутскай: Кинигэ изд-вота, 1991. - 72c.

\section{Процесс адаптации молодого педагога на новом рабочем месте}

\section{Прядезникова А.А., студентка, Северо-Восточный федеральный университет, 2. Якутск E-mail: AilitaVinokurova@mail.ru}

Научный руководитель: к.психол.н., доцент Михалева А.Б.

В настоящее время в школах большую часть учителей составляют педагоги в возрасте. Тут стает проблема омоложения педагогического коллектива. В начале учебного года в школу приходят молодые специалисты, которые только что окончившие учебное заведение. Молодые педагоги сталкиваются с проблемой адаптации на новом рабочем месте. Начинающий учитель при работе в школе теряется. Полученные знания 